\title{
Shear Wave Velocity Estimation by a Joint Inversion of HVSR and f-k Curves under Diffuse Field Assumption: A Case Study of Sobradinho Landslide Estimativa de Velocidade de Onda de Cisalhamento pela Inversão Conjunta de Curvas HVSR e f-k sob a Hipótese do Campo Difuso: um Estudo de Caso do Deslizamento de Sobradinho
}

\author{
Yawar Hussain ${ }^{1}$; Martin Cardenas-Soto ${ }^{2}$; Rogério Uagoda ${ }^{3}$; Salvatore Martino ${ }^{4}$; \\ Nelson Padron Sanchez ${ }^{1}$; César Augusto Moreira ${ }^{5} \&$ Hernan Martinez-Carvajal $^{6}$
}

\author{
${ }^{1}$ University of Brasilia, Department of Civil and Environmental Engineering, SG-12, 70.910-900, Asa Norte, Brasilia, DF, Brazil \\ ${ }^{2}$ National Autonomous University of Mexico, Engineering Faculty, \\ Av. Universidad, 3000, C. U., Coyoacán, C.P. 04510, Mexico City, Mexico \\ ${ }^{3}$ University of Brasilia, Post-Graduation Program in Geography, ICC Norte, 70.910-900, Brasilia, DF, Brazil \\ ${ }^{4}$ University of Rome "Sapienza", Department of Earth Sciences and Research Center for Geological Risks (CERI), \\ P.le A. Moro, 5, 00185 Roma, Italy \\ ${ }^{5}$ Universidade Estadual Paulista (UNESP), Geosciences and Exact Sciences Institute (IGCE), \\ 24-A avenue, 1515 Bela Vista, Rio Claro, Sao Paulo 13506-900, Brazil. \\ ${ }^{6}$ National University of Colombia at Medellín, Faculty of Mines, Cl. 59a, No. 63-20, Medellín, Colombia \\ E-mails:yawar.pgn@gmail.com; mcardenass@gmail.com; rogeriouagoda@unb.br; \\ salvatore.martino@uniromal.it; nelsonwerpnsn@gmail.commreirac@rc.unesp.br; hmartinezc30@gmail.com \\ Recebido em: 16/11/2018 Aprovado em: 01/02/2019 \\ DOI: http://dx.doi.org/10.11137/2019_1_742_750
}

\begin{abstract}
Brazilian landslides are characterized as shallow, clay rich and are commonly triggered by the summer rainfalls. Therefore, the landslide geological information, such as shear surface location, has a paramount importance in their mechanism comprehension. The most adapted methods for the estimation of shear wave velocity profile are borehole stratigraphic logs or Standard Penetration Test (SPT) and Cone Penetration Test (CPT). However, the present study applied shear wave velocity estimation of Sobradinho landslide (SLS) by a joint inversion of horizontal to vertical spectral ratio (HVSR) curve and dispersion curve (DC) extracted from frequency-wavenumber (f-k) analysis of ambient noise records. HVSR curves at all the stations in the area exhibit the ubiquitous resonance frequency peak at $2 \mathrm{~Hz}$ indicates that at these stations the substratum is common. The f-k results for E-W component let us obtain an acceptable DC between 5 and $7 \mathrm{~Hz}$ range. Finally, joint inversion was interpreted based on the diffuse field assumption. The initial model was proposed to be a three-layered over a half-space. Results of joint inversion indicate that the substratum is at 24 $\mathrm{m}$ depth, with Vs values close to $1500 \mathrm{~m} / \mathrm{s}$. DC defines two layers overlaying the substratum: superficial layer with velocities near to $200 \mathrm{~m} / \mathrm{s}$ (7m thick), and the second layer with Vs value of $1000 \mathrm{~m} / \mathrm{s}$. We think that abrupt rheology (stiffness) change between the first and the second layer could provide an evidence of the landslide re-activation during moderate to strong rainfall events. The proposed methodology will prove a reconnaissance survey for the detailed geotechnical investigations that will confirm the obtained results.
\end{abstract} Keywords: ambient seismic noise; rheology; slip surface

Resumo

Os deslizamentos de terra brasileiros são caracterizados como superficiais, argilosos e são comumente desencadeados pelas chuvas de verão. Portanto, a informação geológica do deslizamento de terra, como a localização da superfície de cisalhamento, tem uma importância primordial em sua compreensão do mecanismo. O método de invasão geotécnica mais adaptado para a estimativa do perfil da onda de cisalhamento são os registros estratigráficos do furo ou o Teste de Penetração Padrão (SPT) e o Teste de Penetração do Cone (CPT). No entanto, o presente estudo aplicou a estimativa da velocidade da onda de cisalhamento do deslizamento de terra de Sobradinho (SLS) por uma inversão das articulações da curva de dispersão horizontal e vertical (HVSR) e curva de dispersão (DC) extraída da análise de frequência-número de onda (f-k). As curvas HVSR em todas as estações na área exibem o pico de frequência de ressonância onipresente a $2 \mathrm{~Hz}$ indica que nessas estações o substrato é comum. Os resultados de f-k para o componente E-W nos permitem obter uma CC aceitável entre 5 e $7 \mathrm{~Hz}$. Finalmente, a inversão das articulações foi interpretada com base na suposição do campo difuso. O modelo inicial foi proposto para ser uma camada de três camadas em um meio de espaço. Os resultados da inversão das juntas indicam que o substrato tem profundidade de $24 \mathrm{~m}$, com valores de Vs próximos de $1500 \mathrm{~m} / \mathrm{s}$. DC define duas camadas sobrepostas ao substrato: camada superficial com velocidades próximas a $200 \mathrm{~m} / \mathrm{s}$ (7 m de espessura) e a segunda camada com valor Vs de $1000 \mathrm{~m} / \mathrm{s}$. Nós pensamos que a mudança de reologia abrupta entre a primeira e a segunda camada poderia fornecer uma evidência da reativação do deslizamento de terras durante eventos de chuva moderados a fortes. A metodologia proposta provará uma pesquisa de reconhecimento para as investigações geotecnicas detalhadas que confirmarão os resultados obtidos.

Palavras-Chave: Ruído sísmico; Reologia; Superfície de deslizamento 


\section{Introduction}

Landslide (LS) failures may seriously damage the human and environmental resources of the affected region. Shallow and rainfall triggered clay rich landslides have a greater share in the global terrestrial hazards. These landslides are usually subjected to rapid acceleration due to periods of intense (seasonal) rainfalls (change in stiffness). Under these circumstances the landslide site characterization (delineation of slip surface) helps in the landslide hazard management.

As slip surfaces generates shear wave velocity contrasts due to decrease in shear strength at the unstable zone and it can be detected by variations in Vs. Detailed engineering-geological data to perform slope stability analysis can be derived from conventional geotechnical methods (e.g., penetration tests and trenching). The limitation arises due to trough trains of steep slopes and measuring viscoplastic properties of the fine grained material.

Near surface geophysical methods especially, the surface wave methods have proved very effective in estimation of Vs on various landslides (Cox et al., 2010). In these methods, the energetic part of the seismic wave is used that can be extracted either by array method or by single station method or so called horizontal to vertical spectral ratio (HVSR) (Nakamura 1989; Lermo \& Chavez-Garca 1994). In the first method, the surface waves are obtained from the dispersion curve (frequency-dependent phase velocity), which says that in the case of traveling surface waves, each frequency has its own propagation velocity. There are different array analysis that can be applied for the extraction of dispersion curve (DC) from the waves traveling along the array aperture like active (SASW and MASW methods) and passive methods (SPAC, f-k, Seismic Interferometry). DC is then inverted for the shear wave velocity estimation. However, the inversion of DC alone is uncertain, especially below the fundamental frequency of the medium, because of the filtering effects of the media. In order to avoid these uncertainties, joint inversions of DC and horizontal to vertical spectral ratio (HVSR) curves are recommended (Ullah \& Prado, 2017). In HVSR technique, the spectral ratio of horizontal to vertical components of recorded ambient vibration is obtained. The peak of this curve is related with shear wave velocity of the medium (Pazzi et al., 2017).

In this study, we applied ambient seismic noise based techniques as single-station (e.g., HVSR) and multi-station array (e.g., frequency-wavenumber) (f$\mathrm{k})$ for the estimation of vertical profile of the ground. Particular emphasis is placed on determining the depth of the potential shear surface and investigating the base of the Sobradinho landslide in the Ribeirão Contagem watershed. To this end, a joint inversion is done based on diffuse wavefield assumption which results in shear wave (Vs), P-wave (Vp) and rock densities of the subsurface layers.

\section{Material and Methods 2.1 Sobradinho Landslide}

The Ribeirão Contagem watershed has an area of $146 \mathrm{~km}^{2}$, is located in the northern part of the Federal District of Brazil in the Sobradinho administrative unit. The areas in watershed show erosive susceptibility and consequent possible landslides areas. The curvature map shows the concentration of the erosive features on the concave slopes. The drainage and channel densities of the watershed are $5.7 \mathrm{~km} / \mathrm{km}^{2}$ and 32.9 channels $/ \mathrm{km}^{2}$ (Ferreira \& Uagoda, 2015). There is an intense limestone mining in the study area. The climate of the area is semi-humid tropical with rainy summer and dry winter. The mean annual precipitation in the area is of $1,442.5$ $\mathrm{mm}$ and it is mainly related to rainfalls.

The landslide chosen for this study is located in Federal District near a livestock farm in a small vicinity naming 'Rua do Matto'. The study area is shown in Figure 1. The studied landslide is E-W trending rototranslational earth-slide (Varnes, 1978). The landslide mass is approximately $150 \mathrm{~m}$ long and about $70 \mathrm{~m}$ wide. Along with the main scarp at the top there is a small scarp in the middle which is created by a $2 \mathrm{~m}$ height normal fault originated by the release effect of the Contagem River which cuts the slope at its bottom (Figure 1). The erosional potential of the river is related to rainfall in the surrounding areas which is quite high during rainy season. 




Figure 1 Starting from top to right: location of Federal District on map of Brazil, position of Ribeirão Contagem watershed on Federal District and lithological units of the watershed. Geomorphological units (bottom left), zoomed image along with seismic sensor locations (bottom right).

The main observed cultural activities that are the sources of ambient noise along with natural sources of noise, are workers at the farm, working of electrical motor, activities of cows in the form, mining activities (e.g., workers, rockfall, trucks and other engine vibrations) and village (Rua do Matto) near to the test site (Hussain et al., 2017).

\subsection{Geology and Geotechnical Parameters}

The Federal District covers eastern part of the Tocantins Province. The Brasiliano orogenic event (end of Neoproterozoic, some $570 \mathrm{Ma}$ ) that is ranked into five deformational phases, is responsible for the Litho-structural changes that had occurred in the past. Towards San Francisco Craton this cycle is characterized as compressive tectonics, whi- ch presents first of these four stages with folds and ductile-brittle faults that were responsible for both dome formation (the Brasilia, the Pipiripau and Sobradinho domes) as well as structural basin creation. The geology of Brasilia has been revised and updated in the form of new geological map at 1:100,000 scale. On this new map, four lithological boundaries were distinguished: (i) Paranoá (metasedimentary rocks), Canastra (phyllites), (ii) Araxá (schists), (iii) Bambuí (clayed metasiltites rolled, clay and metasiltites banks) and (iv) Groups and soil or waste shallow colluvial deposits. These lithological units are present in reverse successions where the younger litho-structral unit lies above the older ones. The geological setting of the aforementioned succession is mainly related to thrust faulting (Campos, 2004). 
The studied area is geologically composed of meta-sedimentary rocks of Proterozoic age that were deformed during the Brasiliano Cycle (650 My) covered by a thick weathering mantle (Zoby, 1999). The Sobradinho Unit, of Votorantim Cimentos Brazil, is located in the Ribeirão Contagem Basin, in which low-grade metamorphic sediments of the Paranoá and Canastra groups occur. The Federal District, more specifically its north-central portion, is in the domain of the Tocantins Structural Province, in the Brasília Dobramentos Range; where rocks are attributed to the Canastra, Paranoá, Araxá and Bambuí groups of Proterozoic ages (Canastra and Paranoá groups $\sim 1,100$ million years old and Araxá and Bambuí groups $\sim 700$ million years old). The geology of area consists of Paranoá group (metasedimentary rocks). The lithological units of the are obtained from the groundwater well of ADASA, that lies near the study area (Figure 2).
There are three slopes on the Contagem River side as open concavity, close concavity and a landslide that represent the three geomorphological processes at work. For the identification of various materials in the area material strength analysis was performed, an important step for the understanding its geomorphology. The collected soil samples were tested by the Braga et al. (2018) using granulometric analysis. The soil color was measured through the Münsell Chart, with the soil moisture, in the field. The soil/rock contact information was inferred from the soil color and the acquired data are reported as stratigraphic logs. The undisturbed soil samples were also taken in the trenches dug at different depths. The shear tests on these samples were performed in the Geotechnical Laboratory of the University of Brasilia. The Mohr-coulomb resistance envelope was calculated according to equation 1 .

$$
\tau=\mathrm{c}+\sigma \operatorname{tg} \phi
$$

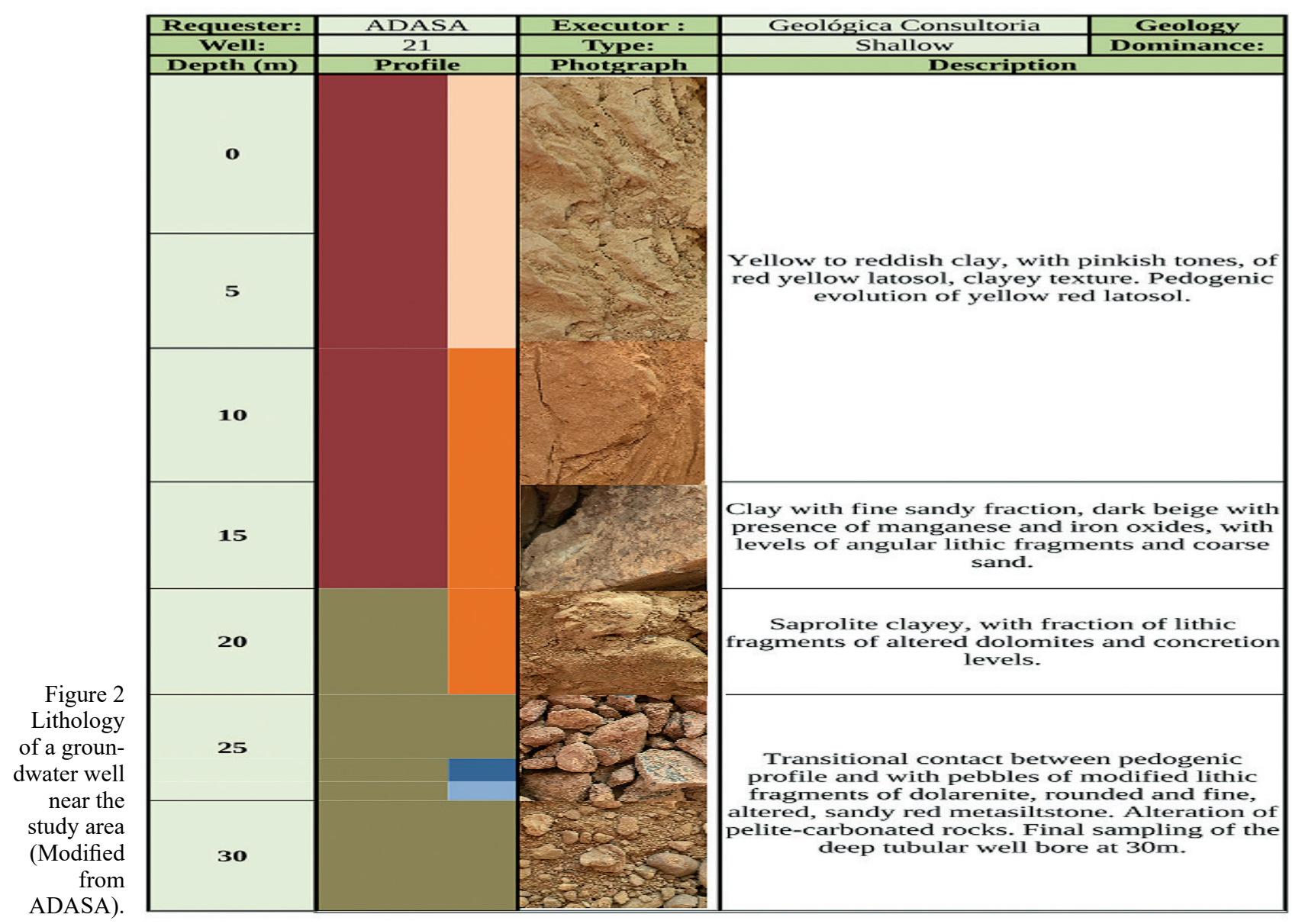


Shear Wave Velocity Estimation by a Joint Inversion of HVSR and f-k

Curves under Diffuse Field Assumption: A Case Study of Sobradinho Landslide

YawarHussain; Martin Cardenas-Soto; Rogério Uagoda; Salvatore Martino; Nelson Padron Sanchez; CésarAugusto Moreira \& Hernan Martinez-Carvajal

\begin{tabular}{|c|c|l|c|c|}
\hline $\begin{array}{c}\text { Declination } \\
\text { (degree) }\end{array}$ & $\begin{array}{c}\text { Shear } \\
\text { Stress(T) }\end{array}$ & $\begin{array}{c}\text { Material } \\
\text { Type }\end{array}$ & $\begin{array}{c}\text { Cohesion } \\
(\mathbf{c})\end{array}$ & $\begin{array}{c}\text { Frictional Angle } \\
(\boldsymbol{\phi})\end{array}$ \\
\hline 7 & 51.47 & Saprolite & 38.36 & 33 \\
\hline 30 & 39.43 & Colluvium & 18.72 & 46 \\
\hline 5 & 30.93 & Alluvium & 9.84 & 33 \\
\hline 9 & 43.76 & Saprolite & 26.34 & 38 \\
\hline 45 & 50.6 & Saprolite & 20.74 & 46 \\
\hline 22 & 68.11 & Saprolite & 44.9 & 43 \\
\hline
\end{tabular}

Table 1 Shear strength parameters of soil of the study area (Braga et al., 2018).

\subsection{Ambient Noise Acquisition}

A generic term used to define the ambient vibrations of ground caused by sources such as tide, turbulent wind, effects of wind on trees or buildings, industrial machinery, cars and trains, or human footsteps are called ambient noise. Based on the frequency contents, there are two sources of noise as natural and cultural commonly referred to as microseisms (below $1 \mathrm{~Hz}$ ) and microtremors (above $1 \mathrm{~Hz}$ ), respectively (Hussain et al., 2017). The ambient is abundant of surface waves because many of the sources of microtremors acting on the earth surface (Okada, 2003). The ambient noise recording has been made following the guidelines developed under the SESAME (2004) recommendations. The measurements were performed in 2016 and 2017 with acquisition system consisted of nine short period seismometers (2 Hz) datalogger RefTek-130, nine GPS locks. The stations recording was done in a continuous mode at 250 sample per second in the north-south (N-S), the east-west (E-W), and the up-down (Z) directions. Stations S1 to S4 lie inside and S5 to S9 lie outside the landslide (Figure 1). One hour of ambient noise record along with its power spectra and spectrogram are plotted in Figure 3.

\subsection{HVSR}

The single-station horizontal to vertical ratio technique is the most adopted technique. In first step, Fourier spectra of north-south, east-west and vertical components are calculated. Then in second step, spectra of both horizontal components are averaged (contains Rayleigh and Love waves) and are divided by the spectra of vertical component, that results in HVSR curve as a function of frequency. The peak of HVSR curve is related to the resonance of subsoil stratigraphic profile (Hussain et al., 2019).

Three main physical reason for the interpretations of HVSR spectral ratio is based on different viewpoints. In the first view point HVSR peak is explained interm of Rayleigh wave ellipticity of around the fundamental frequency of site provided that there exists a sharp impedance contrast between the soil and bedrock (Hussain et al., 2019 and references there in). In the second view the HVSR peak is considered to be related with the transfer function

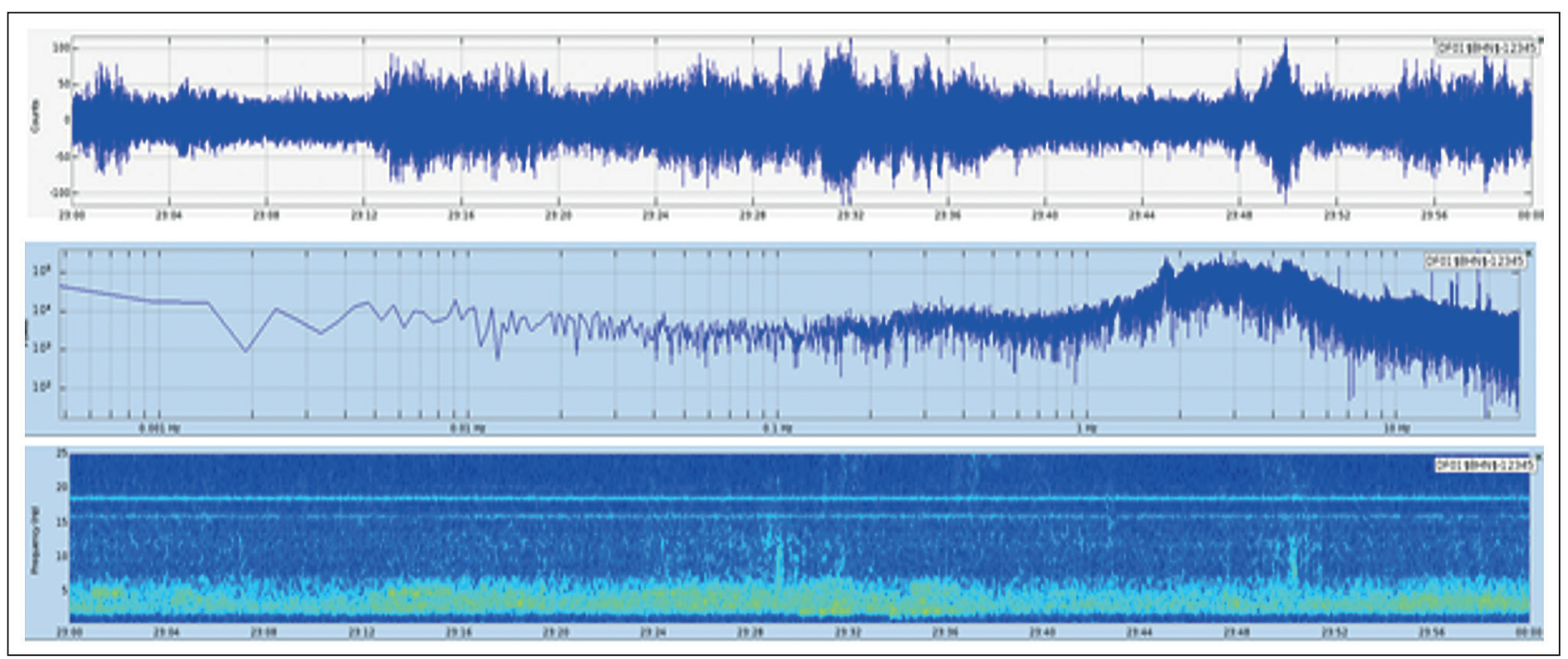

Figure 3 One-hour raw ambient noise record at station S1 (above), power spectra (middle) and spectrogram (bottom). 
of vertical polarized SH waves (Nakamura, 1989) or the $\mathrm{S}$ wave amplification.

The third view point is based on the assumption of diffuse wave field, where the microtremor is treated as a diffuse field which contains both surface (Love and Rayleigh) and body (P and S) waves (Sánchez-Sesma et al., 2011). The intensity of spectral directivity represents the amplitude difference between two horizontal components at a specific frequency. The special case where there is no amplitude difference exists, the intensity of spectral directivity (ISD) equal to unit. The directional field intensity (DFI) contains scattering effects of near surface heterogeneous media. The autocorrelation of motion at receive is proportional to the DFI which in turn related to the imaginary part of green tensor provided that source and sensor lie at the same point (Ullah et al., 2017 and references there in).

\subsection{Frequency Wave-number (f-k)}

There are two most adopted methods used for the detection of surface waves in microtremor as 1) frequency-wavenumber spectral method (f-k method) and 2) spatial autocorrelation method (SPAC method). The f-k method is an application of the technique developed in the United States in the late 1960s to detect nuclear explosions (Okada, 2003). The f-k method is based on a frequency-wavenumber power spectrum estimate, it is assumed that microtremor is a stochastic process in space and time (Okada, 2003). The apparent phase velocity and wave propagation direction along the array were obtained by picking of local maxima of power spectrum (Lacoss et al., 1969). This spectrum is a function of array geometry (aperture) and is reliable at specific interval of wave-numbers. Here, the lower resolution is a function of interstation distance or array aperture as well upper resolution limit is related with station spacing or the minimum interstation distance. This means that a denser and larger array will provide broader interval of wave-numbers and it improved the resolution of the analysis.

\subsection{Joint Inversion}

It is convenient to use complimentary information along with HVSR alone, because of non-uniqueness in the inversion. This problem of non-uniqueness can be mitigated by adopting a joint inversion. As HVSR is a local measure, calculated only at single location and DC is measured at multiple locations (more than one stations), so the inversion includes both Love and Rayleigh waves fundamental modes.

In the first step of processing the recorded noise is converted to SAC format from RefTek for further processing. Then for the fundamental frequency of the site a window of one-hour recording was processed and the reliability condition proposed by Sánchez-Sesma et al. (2011) for the HVSR curve and peak were followed. The processing was carried out in the Hv-Inv software (García-Jerez et al., 2013; Piña-Flores et al., 2016). The two curves (HVSR and $\mathrm{f}-\mathrm{k})$ were loaded in the software. The initial model was proposed to be of three layered over a halfspace. The 4-layered is an appropriate model, where as one or two layer is very simple, and four layered become too complicated. The four layered model let us fit the dispersion curve (DC) at 6 and $7.5 \mathrm{~Hz}$ frequency range. The value of density is fixed. Poisson ratio is less than 0.45 . Started the inversion with the first method Monte-Carlo sampling and finished with Simplex Downhill and Interior-Point methods.

\section{Results and Discussions}

In Sobradinho landslide, the geology of the area is not changing much. HVSR spectral ratios at eight stations exhibit the same form and the site frequency lies at is $2 \mathrm{~Hz}$ with relative amplification of 7 , indicating that under these stations the subsoil structures are very similar. Figure 4 shows a common HVSR ratio where we can see a well define curve that could be related to ellipticity of surface waves. The peak shows that basement lies at relatively greater depth. The fundamental Rayleigh mode associated with the profiles of Figure 4 is very close to the experimental one and is good in common frequency range. If this is the case, the subsoil structure represents a potential landslide risk.

In order to establish a subsoil model that could explain the elastic characteristics related to the soft soils, we have derived a dispersion curve by mean of $\mathrm{f}-\mathrm{k}$ analysis using the V-shaped array of the three components ground motion seismometers. For this, we use 5 seconds time windows along one hour of seismic noise. In Figure 5 phase velocities values of one hour time windows for frequency range (5-10 $\mathrm{Hz}$ ) are given for E-W component. A large dispersion is observed between $5-6 \mathrm{~Hz}$ frequency range 


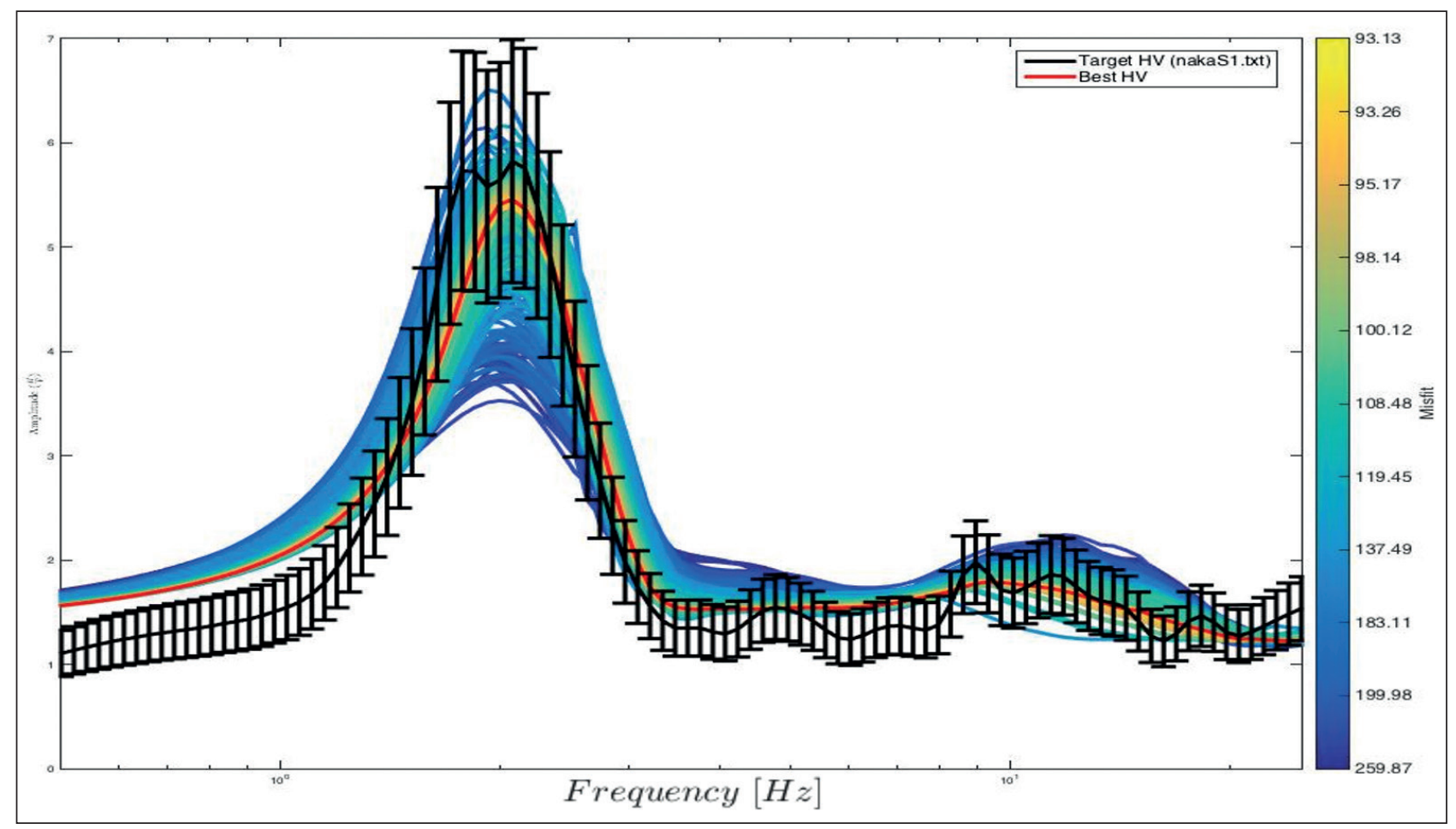

Figure 4 HVSR curve at S1 station (black line) and its standard deviation and set of solutions (color lines) of joint inversion results. The best fit curve is the red color line. Bar scale color indicates the best misfit curves to experimental HVSR curve.

where the incoming wave-field comes from 260 degrees. At frequency of $5 \mathrm{~Hz}$ the phase velocity is $1400 \mathrm{~m} / \mathrm{s}$ which is reduced to $200 \mathrm{~m} / \mathrm{s}$ at $8 \mathrm{~Hz}$. Below $2 \mathrm{~Hz}$ the information is not reliable because of the frequency response of the seismometers used for the analysis or small aperture array. Results for other components of the ambient noise record do not exhibit robust curves.

The curves of the spectral ratios and dispersion that are shown in Figures 4 and 5 respectively, suggest that it is possible to carry out a joint inversion following HV-Inv software guidelines. For the inversion, we start with a four-layer model of constant wave velocity (e.g., Vs, Vp) and density values. In the Figures 4 and 5 we have included the bestfit to experimental curves after using several approximations. We can observe a reasonable fit between model and experimental results in all frequency ranges which are being resolved, which indicate that fundamental Rayleigh mode dominates the ambient seismic noise records.

In the Figure 6, we show a final model and besides Vs, Vp and density structures are also resolved. These parameters are important in the interpretation of landslide characteristics.
The interfaces (probable slip surfaces) lie at 7, 12 and $24 \mathrm{~m}$ depth. These layers have different rigidity values that give rise in the variations of observed seismic characteristics. The depth of bedrock for Vs model is found at $24 \mathrm{~m}$ depth in the area (Figure 6). As slip surfaces may generate shear wave velocity contrasts, the changes in rheology at these interfaces may result in the reactivation of landslide at the extinct slip surface or at a new slip surface developed at the other material interfaces.

The following Vs based stratigraphic model (probable slip surfaces) is developed to explain the subsurface geophysical characteristics: (i) an upper zone of highly fractured material with low seismic velocity (0 to $8 \mathrm{~m}$ depth); (ii) a middle zone with increased stiffness, from 8 to $12 \mathrm{~m}$ depth having a higher seismic velocities, which is another probably a slip surface of landslide then a layered from 12 to 24 which is a stratigraphic interface between landslide mass and substratum. Through the inverted Vs velocity value are higher (at $8 \mathrm{~m} \sim 1000 \mathrm{~m} / \mathrm{s}$ ), they can generate a possibly shear surface for the occurrence of landslide, and (iii) bedrock corresponding to elastic half-space. 
Shear Wave Velocity Estimation by a Joint Inversion of HVSR and f-k

Curves under Diffuse Field Assumption: A Case Study of Sobradinho Landslide

YawarHussain; Martin Cardenas-Soto; Rogério Uagoda; Salvatore Martino; Nelson Padron Sanchez; CésarAugusto Moreira \& Hernan Martinez-Carvajal

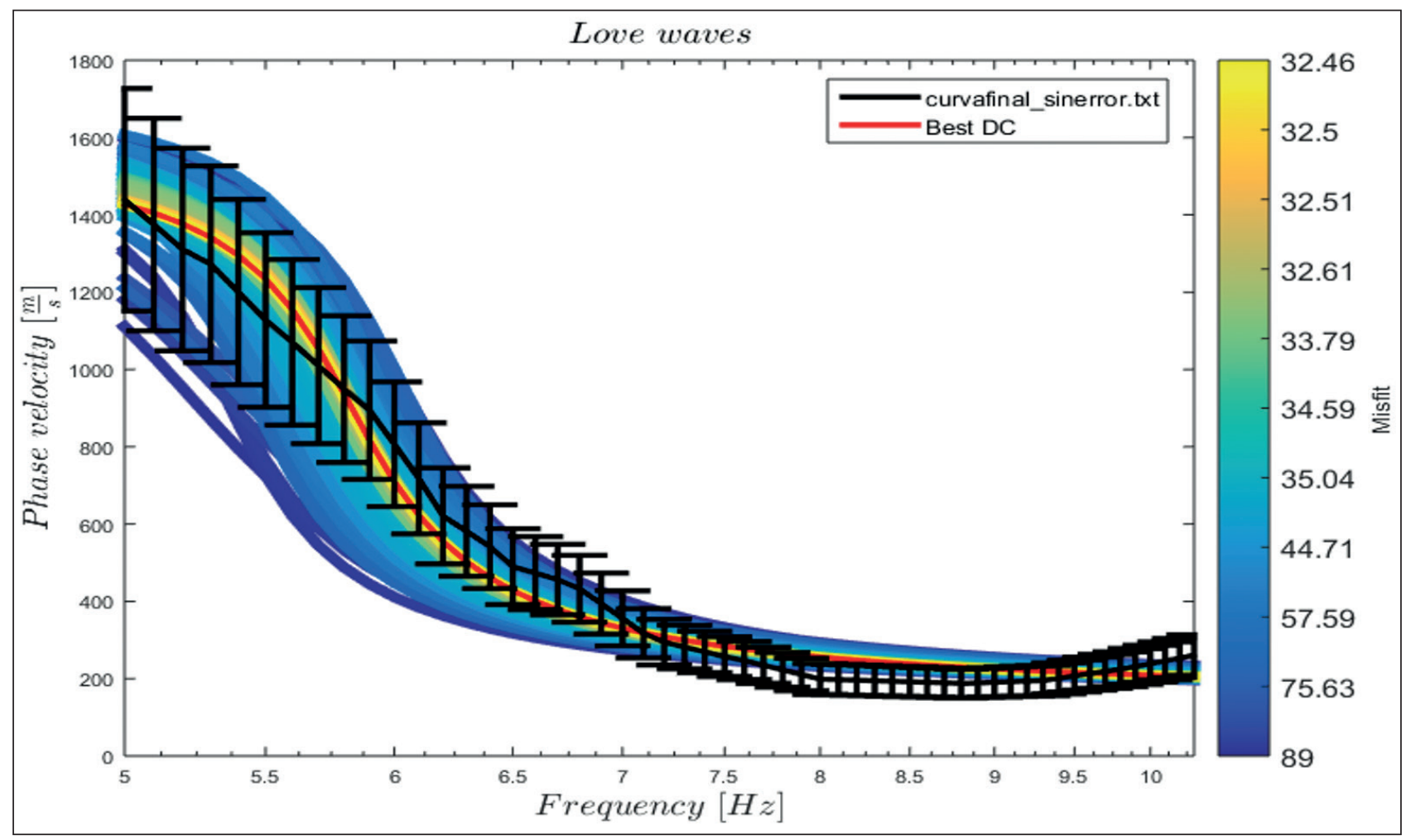

Figure 5 Set of solutions (color lines) of joint inversion results for $\mathrm{f}-\mathrm{k}$ dispersion curve (black line). The best fit curve is the red color line. Bar scale color indicates the best misfit curves to experimental HVSR curve.

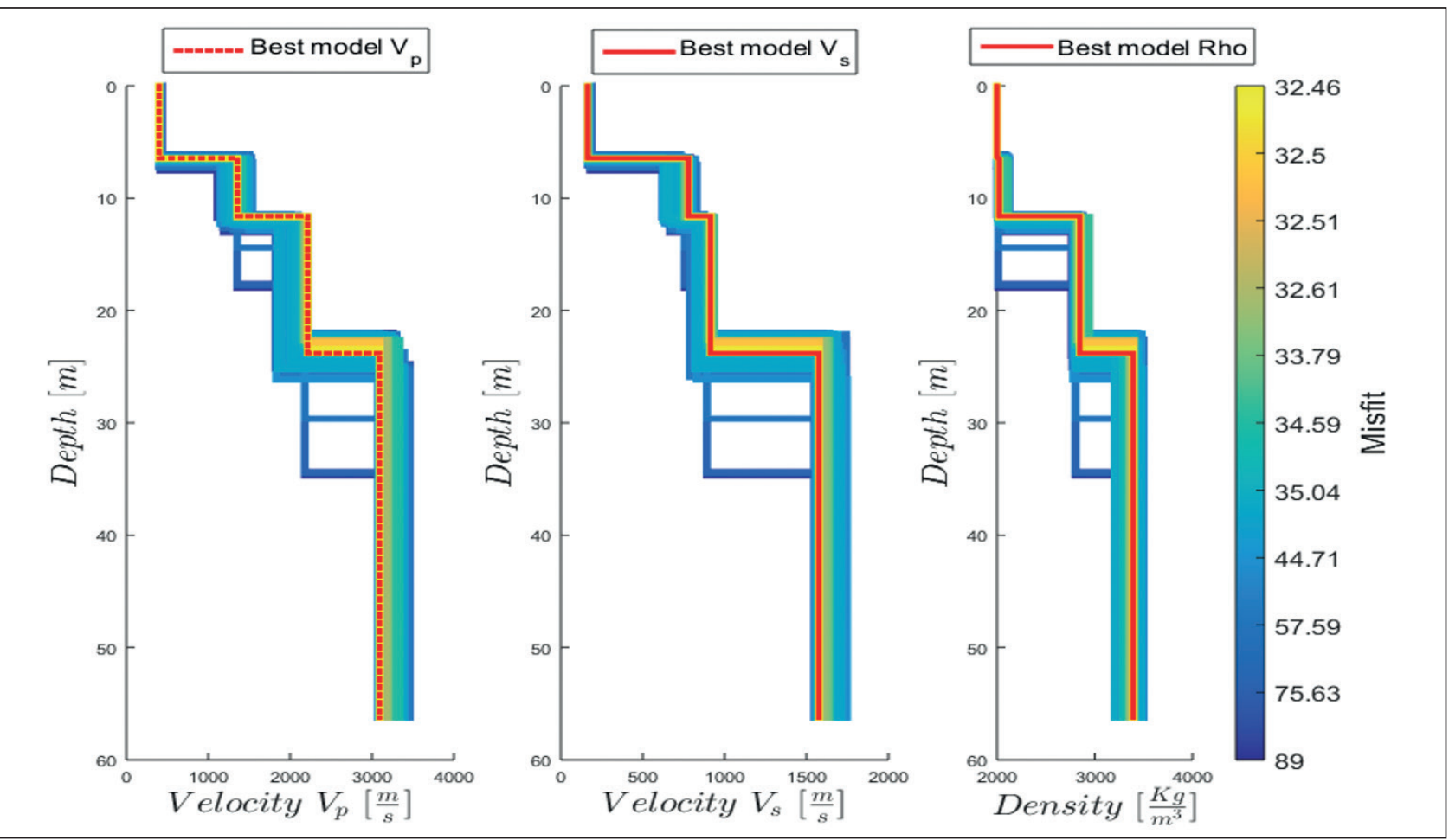

Figure 6 Set of solutions (color lines) of joint inversion results for final subsoil models. The best fit curve is the red color line. Bar scale color indicates the best mistfit curves to experimental HVSR curve. 


\section{Conclusions}

This study was carried out for the determination of shear wave velocity profile of the Sobradinho landslide in Brasilia, Brazil as well as to locate possible surfaces of reactivation using a joint inversion between HVSR and DC (obtained from f-k analysis of ambient noise). Following conclusions are drawn from this study:

HVSR shows a uniform peak at $2 \mathrm{~Hz}$ that is related with the stratigraphy of the area. This peak shows a relatively deeper bedrock in the area.

From $\mathrm{f}-\mathrm{k}$ analysis it is concluded that waves come at 260 degree azimuth which are devoid of surface waves at higher frequencies (greater than 7 $\mathrm{Hz}$ ), while at frequencies below $7 \mathrm{~Hz}$ there is change in velocity because of frequency. These frequency dependent variations in velocity indicate a presence of surface waves.

Shear wave velocities present a three layered stratigraphy at 7, 12 and $24 \mathrm{~m}$ depth. The authors have assumed that the abrupt rheology change between the first and the second layer could be significant to trigger (reactivation) a landslide during a moderate or strong rainfall event. As a future perspective change in the stiffness and/or in the local response during and/or after intense rainfalls could be accounted for by new experiments.

\section{Acknowledgments}

The authors acknowledge the support of the following agencies: The National Council for Scientific and Technological Development (CNPq), the Support Research of the Federal District Foundation (FAP-DF), the University of Brasilia and, the Pool of Brazilian Equipments (PegBr), Rio de Janeiro.

\section{References}

Braga, L.M.; Caldeira, D.; da Silva Nunes, G.J.; Hussain, Y.; Martinez-Carvajal, H. \& Uagoda, R. 2018. Geomorphological Description and Erosive-Depositional Dynamics of Hillslopes on Ribeirão Contagen Fluvial Valley-DF. Anuário do Instituto de Geociências, 41(2): 51-65.

Campos, J.E.G. 2004. Hidrogeologia do Distrito Federal: Bases para a Gestão dos Recursos hídricos Subterrâneos. Revista Brasileira de Geociências, 34(1): 41-48.

Cox, B.R. \& Beekman, A.N. 2010. Intramethod Variability in ReMi Dispersion Measurements and V s Estimates at Shallow Bedrock Sites. Journal of Geotechnical and Geoenvironmental Engineering, 137(4): 354-362.

Ferreira, R.S. \& Uagoda, R. 2015. Morphometric study of controls to
Erosional Features and identification of areas susceptible to Mass Movement Hazards in the Contagem Watershed, Distrito Federal. Espaço \& Geografia, 18(1): 187-216.

García-Jerez, A.; Luzón, F.; Sánchez-Sesma, F.J.; Lunedei, E.; Albarello, D.; Santoyo, M.A. \& Almendros, J., 2013. Diffuse elastic wavefield within a simple crustal model. Some consequences for low and high frequencies. Journal of Geophysical Research, 118(10): 5577-5595.

Hussain, Y.; Martinez-Carvajal, H.; Cárdenas-Soto, M.; Uagoda, R.; Martino, S. \& Hussain, B.M. 2017. Microtremor response of a mass movement in Federal district of Brazil. Anuário do Instituto de Geociências, 40(3): 212-221.

Hussain, Y.; Martinez-Carvajal, H.; Condori, C.; Uagoda, R.; Cárdenas-Soto, M.; Cavalcante, A.L.B.; da Cunha, L.S. \& Martino, S. 2019. Ambient Seismic Noise: a continuous source for the dynamic monitoring of landslides. Terree Didatica, 15: 1-5.

Lacoss, R.T;, Kelly, E.J. \& Toksöz, M.N. 1969. Estimation of seismic noise structure using arrays. Geophysics, 34: 21-38.

Lermo, J. \& Chavez-Garcia, F.J. 1994. Are microtremors useful in the site response evaluation?. Bulletin Seismological Society of America, 84(5): 1350-1364.

Nakamura, Y. 1989. A method for dynamic characteristics estimation of subsurface using microtremor on the ground surface. Quarterly Report of Railway Technical Research Institute, 30(1): 25-33.

Okada, H. 2003. The microtremor survey method Geophysical monograph series 12 American Geophysical Union, Washington, $155 \mathrm{p}$.

Pazzi, V.; Tanteri, L.; Bicocchi, G.; D’Ambrosio, M.; Caselli, A. \& Fanti, R. 2017. H/V measurements as an effective tool for the reliable detection of landslide slip surfaces: Case studies of Castagnola (La Spezia, Italy) and Roccalbegna (Grosseto, Italy). Physics and Chemistry of the Earth, Parts A/B/C, 98:136-153.

Piña-Flores, J.; Perton, M.; García-Jerez, A.; Carmona, E.; Luzón, F.; Molina-Villegas, J.C. \& Sánchez-Sesma, F.J. 2016. The inversion of spectral ratio $\mathrm{H} / \mathrm{V}$ in a layered system using the Diffuse Field Assumption (DFA). Geophysical Journal International, 228(1): 577-588.

Sánchez-Sesma, F.J.; Rodríguez, M.; Iturrarán-Viveros, U.; Luzón, F.; Campillo, M.; Margerin, L.; García-Jerez, A.; Suarez, M.; Santoyo, M.A. \& Rodríguez-Castellanos, A., 2011. A theory for microtremor $\mathrm{H} / \mathrm{V}$ spectral ratio: application for a layered medium. Geophysical Journal International, 186(1): 221-225.

SESAME (2004). Guidelines for the Implementation of the H/V Spectral Ratio Technique on

Ambient Vibrations. Measurements, Processing and Interpretation. SESAME European Research Project WP12-D23.12. http://sesame-fp5.obs.ujf-grenoble.fr/Papers/HV_User_Guidelines.pdf.

Ullah, I. \& Prado, R.L. 2017. Soft sediment thickness and shear-wave velocity estimation from the $\mathrm{H} / \mathrm{V}$ technique up to the bedrock at meteorite impact crater site, Sao Paulo city, Brazil. Soil Dynamics and Earthquake Engineering, 94: 215-222.

Ullah, I.; Prado, R.L. \& Lisa, M. 2017. Single-station ellipticity retrieval and its joint inversion with dispersion curve, for a borehole test site. Arabian Journal of Geosciences, 10(14): 316-328.

Varnes, D.J. 1978. Slope movement types and processes. In: SCHUSTER, R.L. \& KRIZEK, R.J. (eds). Landslides: analysis and control. Spec rep 176. Transportation Research Board, National Research Council, Washington, DC, pp. 11-33.

Zoby, J.L.G. 1999. Hidrogeologia de Brasilia-DF, Bacia do Ribeirão Sobradinho. Programa de Pós-graduação em Geociências, Universidade de São Paulo, Dissertação de Mestrado, 178p. 